\title{
Simulating field-scale variability and precision management with a 3D hydrologic cropping systems model
}

\author{
Nicole K. Ward ${ }^{1} \cdot$ Fidel Maureira $^{2}$ - Claudio O. Stöckle ${ }^{2}$ • \\ Erin S. Brooks ${ }^{3} \cdot K_{\text {Kathleen M. Painter }}^{4} \cdot$ Matthew A. Yourek $^{3}$. \\ Caley K. Gasch ${ }^{5}$
}

Published online: 7 April 2017

(C) The Author(s) 2017. This article is an open access publication

\begin{abstract}
Effective variable-rate nitrogen (N) management requires an understanding of temporal variability and field-scale spatial interactions (e.g. lateral redistribution of nutrients). Modeling studies, in conjunction with field data, can improve process understanding of agricultural management. CropSyst-Microbasin (CS-MB) is a fully distributed, 3-dimensional hydrologic cropping systems model that simulates small (10 s of hectares) heterogeneous agricultural watersheds with complex terrain. This study used a highly instrumented 10.9 ha watershed in the Inland Pacific Northwest, USA, to: (1) assess the accuracy of CS-MB simulations of field-scale variability in water transport and crop yield in comparison to observed field data, and (2) quantify differences in simulated yield and farm profitability between variable-rate and uniform fertilizer applications in low, average and high precipitation treatments. During water years 2012 and 2013 (a "water year" refers to October 1st through the following September 30th, where a given water year is named for the calendar year on September 30th), the model simulated surface runoff with a NashSutcliffe efficiency (NSE) of 0.7, periodic soil water content (comparison to seasonal soil core measurements) with a root mean square error (RMSE) $\leq 0.05 \mathrm{~m}^{3} \mathrm{~m}^{-3}$, and continuous
\end{abstract}

Electronic supplementary material The online version of this article (doi:10.1007/s11119-017-9517-6) contains supplementary material, which is available to authorized users.

Nicole K. Ward

nkward@vt.edu

1 Department of Biological Sciences, Virginia Tech, Derring Hall 1027, 926 West Campus Drive, Blacksburg, VA 24061, USA

2 Department of Biological Systems Engineering, Washington State University, Smith Hall 213, 1935 E. Grimes Way, PO Box 646120, Pullman, WA 99164-6120, USA

3 Department of Biological and Agricultural Engineering, University of Idaho, PO Box 442060, Moscow, ID 83844-2060, USA

4 University of Idaho Extension, Boundary County, 6447 Kootenai Street, Bonners Ferry, ID 83805-5005, USA

5 Department of Soil Science, North Dakota State University, Walster Hall 249, PO Box 6050, Fargo, ND 58108-6050, USA 
soil water content (comparison to in situ soil sensors) at 15 of 20 microsites with NSE $\geq 0.4$. The model predicted 2013 field variability in winter wheat yield with RMSE of $1100 \mathrm{~kg} \mathrm{ha}^{-1}$. Simulated uniform N management resulted in $0-35 \mathrm{~kg} \mathrm{ha}^{-1}$ greater field average yield in comparison to variable-rate management. The savings in fertilizer costs under variable-rate $\mathrm{N}$ management resulted in $\$ 23-\$ 32 \mathrm{ha}^{-1}$ greater field average returns to risk. This study demonstrated the capacity of CS-MB to further understanding of simulated and observed field-scale spatial variability and simulated crop response to low, medium and high annual precipitation.

Keywords Cropping systems model $\cdot$ Spatial variability $\cdot$ Variable rate fertilizer · Wheat · Hydrology

\section{Introduction}

Precision, or variable-rate, nitrogen $(\mathrm{N})$ fertilizer management aims to more effectively manage field-scale spatial variability in crop production. Decreasing the amount of $\mathrm{N}$ applied on areas of the field with low yield potential, i.e. the low $\mathrm{N}$ application zone, can maintain yields while reducing input costs, thus increasing farm profits (Baker et al. 2004; Plant et al. 2000). Variable-rate management zones account for spatial variability within a given year (Basso et al. 2009, 2010; Zhang et al. 2010), but an understanding of a zone's temporal stability, including response to different annual precipitation totals, and spatial interactions on a field, such as the lateral redistribution of moisture, would improve the efficacy of variable-rate $\mathrm{N}$ management (Basso et al. 2013; Pan et al. 2006). Variable-rate $\mathrm{N}$ management is especially promising in highly variable landscapes such as the US Inland Pacific Northwest dryland cereal grain producing region (Palouse Region), where in-field winter wheat yield can vary from less than 3000 to over $12000 \mathrm{~kg} \mathrm{ha}^{-1}$ (Yang et al. 1998).

Process-based models, used in conjunction with field data, can contribute to a more holistic understanding of physical and environmental controls on agricultural systems (Palosuo et al. 2011). Field-scale spatial variability has been simulated using point-based crop models to represent field units (Basso et al. 2007; Batchelor et al. 2002). A recent study on irrigated cotton systems used the fully distributed and hydrologically-connected PALMScot model, though sub-surface lateral redistribution of moisture was not simulated (Booker et al. 2015). The ability to simulate the 3-dimensional (3D) sub-surface lateral redistribution of water and nitrogen, which can control total plant available water during the growing season and the timing of water and nitrogen availability, is essential in accurately simulating Palouse fields (Pan et al. 2006).

To assist in examining field-scale variability and precision agriculture, the fully distributed 3D version of CropSyst was developed (Stöckle et al. 2003, 2014). The previous 1-dimensional version of CropSyst has been used to accurately simulate wheat cropping systems with varying climate, soil and management (Palosuo et al. 2011; Singh et al. 2008; Stöckle et al. 2014). This fully distributed model provides fine scale $\left(\leq 100 \mathrm{~m}^{2}\right)$ hydrologic (e.g. soil water content, surface runoff, drainage, etc.), nutrient cycling (e.g. residue production and decomposition) and crop production (e.g. yield, phenology, $\mathrm{N}$ uptake, etc.) information at daily or hourly time-steps. CS-MB, used in conjunction with experimental, remotely sensed or farm implement data could enable researchers to explore spatial 
interactions in the landscape (lateral redistribution of water and nitrogen), spatial variability (snow distribution, soil, topography), along with cropping history, tillage management, fertilizer management and coupled changes in carbon and nitrogen cycling, crop yield and nitrogen uptake, farm profitability and environmental effects ( $\mathrm{N}$ loss).

The overall goal of this study was to compare variable-rate and uniform fertilizer management on a field with complex terrain and variable soil conditions. CS-MB was used for this study because of its unique ability to simulate continuous 3D hydrologic and nutrient processes on small (10 s of hectares) heterogeneous agricultural watersheds and simulate in-season and harvest crop growth. The specific objectives were to: (1) assess the ability of the CS-MB model to predict field-scale variability in water transport and crop yield, and (2) quantify differences in simulated yield and farm profitability between a uniform fertilizer application and a variable-rate fertilizer strategy under simulated low, average and high annual precipitation. This study provides the first assessment of CS-MB and, to the authors' knowledge, the first application of a fully distributed hydrologic cropping systems model for precision $\mathrm{N}$ management at the field-scale.

\section{Methods}

\section{Model description}

CS-MB requires input files of weather, soil physical characteristics, crop rotation, crop management operation and timing, and a digital elevation model (DEM). In CS-MB, the user chooses the grid size according to the availability of input data and specific project objectives. Each grid cell is assigned an elevation value according to the DEM to determine water routing, along with detailed soil files and crop management. The ability to apply unique management to each grid cell enables the user to apply different farming practices across the field, such as applying a variable rate of fertilizer.

The water flow through the soil is calculated using an hourly cascading approach, and allows for free drainage below the simulated soil profile. Sub-surface lateral flow algorithms follow the approach used in the Soil Moisture Routing model (Brooks et al. 2007; Frankenberger et al. 1999) where lateral transport can flow to a cell from each of the eight neighboring cells. Evapotranspiration (ET) is calculated according to the Penman-Monteith model (Monteith 1965) and requires daily maximum and minimum temperature, solar radiation, maximum and minimum relative humidity and wind speed. An ET crop coefficient is used to relate reference crop ET to actual ET for specific crop types when water availability is high, and crop ground cover determines partitioning between crop transpiration and soil evaporation. ET is then limited by water availability in the surface and root zone soil layers (Stöckle et al. 2003).

The nitrogen routines in CropSyst include soil nitrate and ammonium concentrations for each soil layer at a daily time-step, calculated using $\mathrm{N}$ transformations, sorption, gaseous losses and crop $\mathrm{N}$ uptake. Microbially-mediated $\mathrm{N}$ transformations are calculated according to irreversible first order kinetics. Soil carbon and nitrogen dynamics are determined using either single- (Kemanian and Stöckle 2010) or multiple-pool (Stöckle et al. 2012) models of soil organic matter (SOM), with SOM decomposition dependent on soil water and temperature and enhanced by tillage operations, and SOM replenishment dependent on organic residue inputs and their decomposition. Nitrification is based on available ammonium and calculated as a first order rate function of soil water content and 
temperature (Stöckle and Campbell 1989). Denitrification is calculated using a potential denitrification rate modified by nitrate, water and carbon functions (Stöckle et al. 2012). Crop $\mathrm{N}$ uptake is limited by potential nitrogen uptake and crop nitrogen demand. Nitrogen transport is simulated in conjunction with the water transport routines (Stöckle et al. 2003).

Crop phenology is based on thermal time (accumulation of average daily air temperature above a growth base temperature). Water stress accelerates accumulated thermal time (Stöckle et al. 2003). Biomass accumulation is determined by transpiration and transpiration-use efficiency (a function of vapor pressure deficit). At very low vapor pressure deficits, this approach may over-predict biomass production, and biomass production is then limited based on the crop radiation-use efficiency and the amount of crop-intercepted photosynthetically active radiation (Stöckle et al. 2003). Transpiration and crop growth are also limited by nitrogen concentrations and water availability as described in Stöckle et al. (2003). Yield is determined from simulated biomass by using the harvest index, the ratio of the amount of harvestable yield to above-ground biomass.

\section{Site description and field data}

The 10.9 ha study site $\left(46^{\circ} 34^{\prime} \mathrm{N}, 116^{\circ} 35^{\prime} \mathrm{W}\right)$ is located in the Palouse region, where field average dryland winter wheat yield is $6333 \mathrm{~kg} \mathrm{ha}^{-1}$ and commonly exceeds 9 $000 \mathrm{~kg} \mathrm{ha}^{-1}$ (Schillinger et al. 2006). Yield monitor measurements provided by the fieldsite private grower for 2013 soft white winter wheat ranged from 3300 to $9000 \mathrm{~kg} \mathrm{ha}^{-1}$, averaging $6350 \mathrm{~kg} \mathrm{ha}^{-1}$. The Palouse has an annual precipitation of 400-900 mm, with the highest precipitation occurring on the eastern portion of the region (Daly et al. 2008). Precipitation across the region is enough to support dryland production, thus no irrigation is used. The annual precipitation observed at the study site for each year from 2011 to 2016, in consecutive order, were: 583, 638, 604, 502, 608 and $648 \mathrm{~mm}$. The eastern Palouse is dominated by hydraulically restrictive layers (argillic or fragipan horizons) that limit the depth of root penetration and generate perched water tables and sub-surface lateral flow (Brooks et al. 2012). Across the study site, hydraulically restrictive horizons are found between 0.3 and $1.5 \mathrm{~m}$ below the surface, as determined using a $1650 \mathrm{~kg} \mathrm{~m}^{-3}$ bulk density threshold to establish presence of a restrictive horizon (Reuter et al. 1998). Palouse fields have high spatial variability with short and steep (45-55\% slope) northeast facing slopes and longer, more gradual southwest facing slopes (Brooks et al. 2012). The study site is relatively flat in comparison to regional averages with a maximum slope of $17 \%$ and an average of $5 \%$. In these variable landscapes with hydraulically restrictive horizons, subsurface lateral flow is a key, but often overlooked, spatial interaction across the field and a complicating process in predicting yield from periodic soil water and $\mathrm{N}$ measurements (Pan et al. 2006).

The site is privately owned by a co-operator farmer and has been managed in a soft white winter wheat-spring wheat-garbanzo rotation under conservation tillage and variable-rate fertilizer since 2007. In 2013, a variable-rate of Urea Ammonium Nitrate Solution 32-0-0 fertilizer was applied in three fertilizer rate zones: high, medium, and low (Fig. 1). The zones were delineated by the farmer operator using previous years' yield monitor maps, Farm Works Software ${ }^{\circledR}$ (Trimble Ag Software, Hamilton, IN, USA), and personal knowledge of the field. During the 2013 soft white winter wheat production year, $44 \mathrm{~kg}$ $\mathrm{N} \mathrm{ha}{ }^{-1}$ of fertilizer was applied as broadcast spring top-dress across the entire field; the fall soil-incorporated application of $\mathrm{N}$ fertilizer in the high, medium, and low zone were 101 , 78 and $56 \mathrm{~kg}-\mathrm{N} \mathrm{ha}^{-1}$, respectively. 


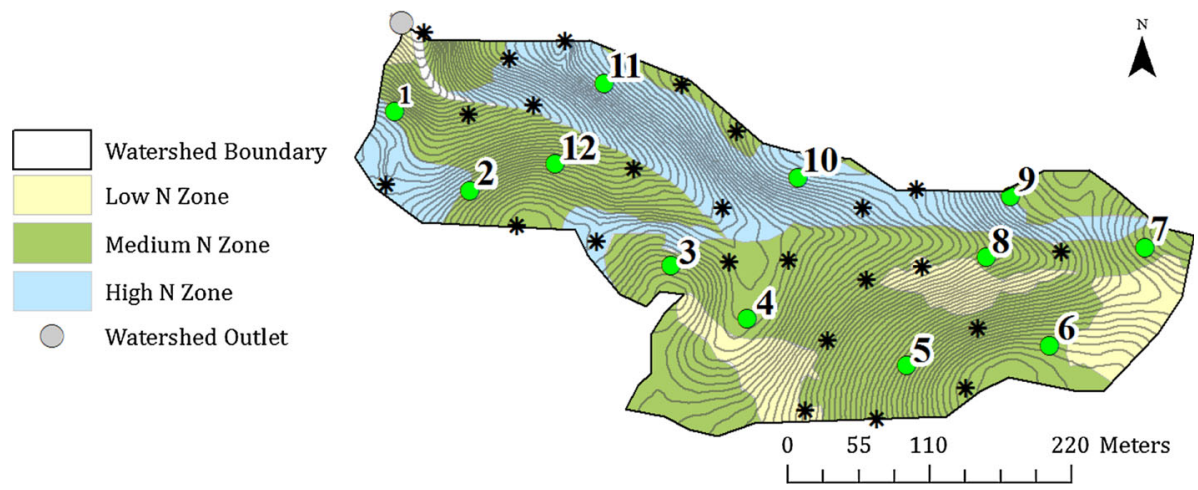

Fig. 1 Map of study site with $0.3 \mathrm{~m}$ contour lines, periodic soil sample sites (Asterisk), intensive soil sample sites (green filled circle) and fertilizer rate zones (Color figure online)

Data collection at the field site included both high temporal frequency automated sampling and manual periodic soil sampling at 12 locations identified using stratified random design based on a cluster analysis of apparent soil electrical conductivity maps and terrain indices (Fig. 1). The sites were based on soil and topographic attributes to capture the spatial variability in water content and crop yield across the field. Five in situ 5TM or 5TE soil sensors (Decagon Devices, Pullman, WA, USA) were installed at each of the 12 intensive sampling sites in fall 2011. At each site, one sensor was placed at each $0.3 \mathrm{~m}$ increment of depth to $1.5 \mathrm{~m}$. The 5TM sensors, which were installed at 10 of the 12 locations, monitor soil moisture and temperature every hour. The 5TE sensors, which were installed at the remaining two locations, monitor soil moisture, temperature and apparent electrical conductivity. Periodic soil measurements were manually taken at the 12 intensive sampling sites and at each of the five monitoring depths. These included gravimetric water content (Gardner 1986) during fall 2011, 2012 and 2013, spring 2012 and 2013, and summer 2013, bulk density (Blake and Hartge 1986) during fall 2011, soil particle size and texture during fall 2011 using the pipette method (Gee and Bauder 1986), total carbon and total nitrogen using a TruSpec combustion analyzer (LECO Corp., St. Joseph, MI, USA) during fall 2011 and 2012 and inorganic $\mathrm{N}$ concentrations using 1.0 M KCl extraction and a Lachat flow injection analyzer (Lachat Instruments, Milwaukee, WI, USA) during fall and spring of 2012 and 2013. Bulk density and particle size were sampled at 24 additional locations. Bulk density was sampled in February 2013 with a hydraulic coring device (Giddings) in the following depth increments: $0-0.1,0.1-0.2,0.20-0.3,0.3-0.6,0.60-0.9$, $0.9-1.2$, and $1.2-1.5 \mathrm{~m}$.

Watershed-level measurements included surface runoff, weather and elevation. Surface runoff was measured at the watershed outlet in a $0.15 \mathrm{~m}$ Parshall flume using a 0-17 $000 \mathrm{~Pa}$ range pressure sensor (Instrumentation Northwest, Kent, WA, USA) connected to a CR200 (Campbell Scientific, Logan, UT, USA) data logger beginning in February, 2012. A HOBO (Onset Corporation, Bourne, MA, USA) weather station was installed in fall 2011 at the field site and provided hourly air temperature, relative humidity, wind speed, wind direction, solar radiation and precipitation. A DEM was developed for the site using a survey-grade global positioning system (GPS) with a vertical accuracy of less than $0.01 \mathrm{~m}$.

Harvest and in-season crop measurements were made at each of the 12 intensive sampling locations. Four $1 \mathrm{~m}^{2}$ samples of winter wheat yield were collected by hand during the 2013 harvest. In-season measurements of winter wheat leaf area index (LAI) 
were measured weekly using a LI-COR model LAI-2 000 plant canopy analyzer (LI-COR, Lincoln, NE, USA) during the growing season.

\section{Objective 1: model assessment}

All simulations in this study were run from October 1st 2010 through September 30th 2013. The accuracy of the CS-MB model was assessed using surface runoff during calendar year 2012 and 2013, periodic soil water content measurements during calendar year 2012 and 2013, in situ continuous water content measurements during water years 2012 and 2013 and observed crop yield in 2013. To minimize the effect of assumed initial conditions on simulated data, a one-year spin-up period was used beginning in fall 2010. The spin-up period is commonly used in process-based modeling to increase confidence that the agreement between model output and field observations are due to accurate simulation of system processes and not simply a result of initial and boundary conditions. Since this study used soil water content as a primary validation metric, a one-water year spin up period was used (October 1st 2010 through September 30th 2011). This ensured that the simulated field was exposed to very wet winter and spring conditions in addition to dry summer conditions before model outputs were compared to observations, giving confidence that the agreement in simulated and observed water content is due to accurate simulation of the processes involved and not just due to legacy effects of the initial water content values. The farm management inputs for the entire simulation period were generated according to on-site farming methods, machinery and timing of operations. All continuous input files adhered to the same 10 by $10 \mathrm{~m}$ grid across the 10.9 ha watershed.

Due to field weather station malfunction in 2012, data gaps occurred in the observational weather dataset. Overall weather station gaps occurred from June 14th to August 2nd 2012, and September 4th-11th, 2012. The anemometer (instrument to measure wind speed) malfunctioned April 14th-September 11th, 2012. The weather data gaps were filled using regressions between observations from January 1st 2012 through September 11th 2014 and nearby weather stations with the measurement of interest. Precipitation gaps were interpolated using the 4 nearest NCDC (National Climatic Data Center) weather stations in a modified normal-ratio method (Searcy and Hardison 1960). Ratios were obtained as the regression slopes (intercept at zero) of observed cumulative precipitation from 2012 to 2014. For air temperature and relative humidity, linear regressions between field site observational data and nearby AgWeatherNet stations on Washington State University's automatic weather data network and Weather Underground, Inc. were used, then average regression-predicted values were used. Solar radiation was filled using the same method as air temperature and relative humidity, with regressions of observed data with WSU's Long-Term Agro-ecosystem Research (LTAR) site (Pullman, WA) and the Pullman, WA, AgWeatherNet station. The root mean square error (RMSE) for the resulting linear regressions were $7.4 \%$ for relative humidity, $1.70^{\circ} \mathrm{C}$ for air temperature, $1.22 \mathrm{~m} \mathrm{~s}^{-1}$ for wind speed, $29 \mathrm{~mm}$ for precipitation, and $68 \mathrm{~W} \mathrm{~m}^{-2}$ for solar radiation. Due to these low RMSE values, the gap filling process was assumed to have minimal effect on the simulation. RMSE is calculated according to Eq. 1, where $p$ is the predicted value and $o$ is the observed value.

$$
R M S E=\sqrt{\overline{(p-o)^{2}}}
$$


Using observational soil data as described in the Site Description and Field Data section, a continuous $10 \mathrm{~m}$ by $10 \mathrm{~m}$ soil profile grid was generated. The methods to extrapolate multiple point-based datasets to a continuous grid are outlined below. Following the described methods, the study site grid resulted in thirty-nine unique soil profiles. Each grid cell in the watershed (1 093 cells in total) was assigned one of the thirtynine soil profiles. Each soil profile was represented with 15 layers extending to a depth of $2.2 \mathrm{~m}$. The layers below $1.5 \mathrm{~m}$ were assumed to be the same as observed at the $1.5 \mathrm{~m}$ depth. The steps used to transform point-based soil data into the final thirty-nine soil files distributed across the watershed were:

1. Bulk density map - bulk density from the 36 soil sample locations was interpolated to a continuous $10 \times 10 \mathrm{~m}$ grid at each of the five monitoring depths (for a total of 180 observations) with automated three-dimensional regression-kriging (as in Hengl et al. 2014). The automated regression-kriging function fits a regression model to describe a mean trend, and then a three-dimensional semi-variogram to account for correlation in residuals. The regression and semi-variogram models are then combined, in regression-kriging, to produce predictions. In the automated mapping, a linear multiple regression model with elevation, slope, planform curvature, profile curvature, apparent electrical conductivity (ECa) and co-ordinates (easting and northing) as spatially exhaustive covariates was used. The apparent electrical conductivity layer was produced from a survey conducted in the fall of 2013 (the dry season) using an EM38-MK2 (Geonics Limited, Mississauga, Ontario, Canada) coupled with an AgGPS 132 differential global positioning system (Trimble, Sunnyvale, CA, USA). The readings from the EM38 were attached to their location every second using the Handheld Geographic Information Systems software package (StarPal, Fort Collins, $\mathrm{CO}$, USA). The effective measurement depth (in vertical dipole orientation) was $1.5 \mathrm{~m}$ (Sudduth et al. 2001) with units of $\mathrm{mS} \mathrm{m}^{-1}$. The instrument was placed in a polyvinyl chloride pipe carrier that was pulled behind an all-terrain vehicle, which was driven in a north-south, east-west grid across the field. The ECa surface was created from survey points ( 3897 points total) using ordinary kriging. The data were randomly split into a training set used for model fitting (70\% of points) and a validation set used to assess prediction accuracy (30\% of points); RMSE of the ECa surface was $2.47 \mathrm{mS} / \mathrm{m}$. The regression model also included a spline interpolation to explain variation in bulk density across depth. In leave-one-location-out cross-validation, the bulk density predictions had an RMSE of $130 \mathrm{~kg} \mathrm{~m}^{-3}$. All geostatistical analyses were conducted in R (R Core Team 2015), using the 'GSIF' package (Hengl 2015), and 'gstat' package (Pebesma 2004), with assistance from the 'aqp' (Beaudette et al. 2013), 'rgdal' (Bivand et al. 2015), 'raster' (Hijmans 2015), and 'plyr' (Wickham 2011) packages.

2. Spatially distributed depth to hydraulically restrictive horizon-depth to restrictive horizon was estimated across the watershed using the spatially distributed bulk density predictions (Step 1) and a $1650 \mathrm{~kg} \mathrm{~m}^{-3}$ bulk density threshold to establish presence of a restrictive horizon (Reuter et al. 1998).

3. Gridded soils - soil layers above the restrictive horizon were assigned field average bulk density for each depth (1 300, 1400 and $1500 \mathrm{~kg} \mathrm{~m}^{-3}$ in the $0-0.1 \mathrm{~m}$, 0.1-0.4 m, and 0.4-1.5 m depths, respectively). Soil layers at or below the depth to restrictive horizon (Step 2) were assigned a bulk density of $1700 \mathrm{~kg} \mathrm{~m}^{-3}$. Clay content, organic matter and initial soil nutrients were assigned to each soil layer based on observations from the nearest intensive sampling site with shared slope and aspect characteristics. Saturation was calculated using observed bulk density $\left(\rho_{b}\right)$ and an 
assumed particle density of $2650 \mathrm{~kg} \mathrm{~m}^{-3}$ (saturation $=1-\left(\rho_{\mathrm{b}} / 2650\right)$, where $\rho_{\mathrm{b}}$ is bulk density). Field capacity (Eq. 2), wilting point (Eq. 3), and saturated hydraulic conductivity (Eq. 4) were determined from locally measured bulk density relationships (Holtan et al. 1968, see supplementary material) and were used to determine moisture tension parameters (Brooks and Corey 1964). The difference between field capacity and saturated water content in these dense soils was not allowed to be less than $3 \%$. Lateral saturated hydraulic conductivity $\left(K_{\text {sat }-L}\right)$ in the top $0.3 \mathrm{~m}$ of soil was $10 \times K_{\text {sat }}$, from 0.3 to $0.6 \mathrm{~m}$ depth, $K_{\text {sat }-L}$ was $5 \times K_{\text {sat }}$, from 0.6 to $0.9 \mathrm{~m}$ depth, $K_{\text {sat }-L}$ was $2 \times$ $K_{\text {sat }}$, and below $0.9 \mathrm{~m}$ depth $K_{\text {sat }-L}$ was equal to $K_{\text {sat }}$ (Brooks et al. 2004).

$$
\begin{gathered}
\theta_{f c}=0.1372 \rho_{\mathrm{b}}+0.1454 \quad\left(R^{2}=0.48\right) \\
\theta_{w p}=0.22 \rho_{\mathrm{b}}-0.15 \quad\left(R^{2}=0.85\right) \\
K_{\text {sat }}=4.957 \rho \mathrm{b}^{2}-16.712 \rho_{\mathrm{b}}+14.122 \quad\left(R^{2}=0.72\right)
\end{gathered}
$$

where $\theta_{f c}$ is volumetric water content of the soil at field capacity, $\theta_{w p}$ is volumetric water content of the soil at wilting point, $\rho_{\mathrm{b}}$ is soil bulk density, and $K_{s a t}$ is the saturated hydraulic conductivity of the soil.

Following general hydrology modelling guidelines, site-specific parameter values were used when possible, focused on calibrating the most uncertain parameters in a stepwise manner, and limited parameter adjustment to within error of initial estimates (Malone et al. 2015). The manual stepwise calibration of water storage and transport parameters $\left(K_{\text {sat }}\right.$, saturation, field capacity, wilting point) enabled an assessment of model accuracy specifically at the highly instrumented and sampled field site followed by an evaluation of fertilizer management scenarios on this particular field. First, since there were no direct observations of $K_{\text {sat }}$, the value was adjusted during calibration within the calculation error (Eq. 4 and Supplementary Material) to maximize the Nash-Sutcliffe Efficiency (NSE, Eq. 5, Nash and Sutcliffe 1970) of watershed runoff.

$$
N S E=1-\frac{\sum_{t=1}^{T}\left(Q_{o}^{t}-Q_{m}^{t}\right)^{2}}{\sum_{t=1}^{T}\left(Q_{o}^{t}-\overline{Q_{o}}\right)^{2}}
$$

where NSE is Nash-Sutcliffe Efficiency, $\mathrm{Q}_{\mathrm{o}}$ is observed discharge at time $t$, and $\mathrm{Q}_{\mathrm{m}}$ is modeled discharge at time $t$. NSE values may range from $-\infty$ to 1 . Perfect model predictions result in an NSE $=1$, model predictions that are as accurate as using the mean of observed values result in an NSE $=0$, and NSE values less than zero indicate that the mean of observed values is a better prediction than modeled values. Second, at sites and depths with continuous in situ- soil sensor data where saturation, field capacity and wilting point could be identified based on soil water patterns and further supported by soil core water observations, the values were manually adjusted in the respective soil files. This manual stepwise hydrologic calibration was used to apply CS-MB to the field site as an evaluation tool to take a first look at how CS-MB was simulating 3D processes on the landscape.

After calibrating the hydrologic components of the model, the winter wheat crop growth parameters were manually calibrated to field average, maximum and minimum crop yield. Crop parameters were adjusted from previously used CropSyst studies according to observed field data and within the range of observed values in the literature (Table 1). Initial and maximum canopy cover, green and total canopy cover at maturity, thermal time at emergence, thermal time at the end of canopy growth, thermal time at the beginning of canopy senescence and thermal time at physiological maturity were adjusted such that in- 
Table 1 Parameters used for soft white winter wheat, including crop growth, morphology, development and nutrient uptake

\begin{tabular}{|c|c|c|c|}
\hline Parameter & Value & Parameter & Value \\
\hline Radiation use efficiency (g/MJ PAR) & 3.0 & C-days at emergence & 100 \\
\hline Water use efficiency at $1 \mathrm{kPa}(\mathrm{g} / \mathrm{kg})$ & 4.7 & $\mathrm{C}$-days at flowering & 1800 \\
\hline Slope of water use efficiency & -0.59 & C-days at start of grain filling & 1950 \\
\hline $\begin{array}{l}\text { Optimum mean daily temperature for growth } \\
\left({ }^{\circ} \mathrm{C}\right)\end{array}$ & 10 & C-days at end of canopy growth & 1750 \\
\hline Initial canopy ground cover $(0-1)$ & 0.01 & C-days at start of senescence & 2000 \\
\hline Max. canopy ground cover $(0-1)$ & 0.86 & Crop ET coefficient & 1.1 \\
\hline Total canopy ground cover at maturity & 0.7 & Max. water uptake (mm/day) & 8 \\
\hline Maximum crop height (m) & 1.3 & Max. N uptake (kg/ha/day) & 4 \\
\hline $\begin{array}{l}\text { Leaf water potential that begins reducing } \\
\text { canopy expansion }(\mathrm{J} / \mathrm{kg})\end{array}$ & -1100 & Wilting leaf water potential $(\mathrm{J} / \mathrm{kg})$ & -1600 \\
\hline $\begin{array}{l}\text { Leaf water potential that stops canopy } \\
\text { expansion }(\mathrm{J} / \mathrm{kg})\end{array}$ & -1500 & $\begin{array}{l}\text { Leaf water potential at the onset of } \\
\text { stomatal closure }(\mathrm{J} / \mathrm{kg})\end{array}$ & -1100 \\
\hline Max. rooting depth $(\mathrm{m})$ & 1.6 & Soil $[N]$ that limits $N$ uptake (ppm) & 3 \\
\hline $\begin{array}{l}\text { Max. surface root density at full rooting depth } \\
\left(\mathrm{m} / \mathrm{m}^{3}\right)\end{array}$ & 70000 & $\begin{array}{l}\text { Plant available water at which } \mathrm{N} \\
\text { limitation begins }(0-1)\end{array}$ & 0.3 \\
\hline $\begin{array}{l}\text { Curvature of root density distribution } \\
(0.001-3)\end{array}$ & 1.8 & Soil $\mathrm{N}$ not available for uptake (ppm) & 0.5 \\
\hline Root length per unit root mass $(\mathrm{km} / \mathrm{kg})$ & 140 & Standard root $[\mathrm{N}](\mathrm{kgN} / \mathrm{kgDM})$ & 0.005 \\
\hline Base temperature for development $\left({ }^{\circ} \mathrm{C}\right)$ & 0 & Root growth sensitivity to stress $(0-1)$ & 0.3 \\
\hline Max. temperature for development $\left({ }^{\circ} \mathrm{C}\right)$ & 26 & Unstressed Harvest Index & 0.48 \\
\hline
\end{tabular}

season simulated potential green area index (GAI) followed the same pattern as maximum LAI observed on the field site. Rooting depth was limited to the upper boundary of the hydraulically restrictive soil horizon (Reuter et al. 1998) and root density and distribution values were based on wheat physiology experimentation in representative soils and similar tillage management to the field site (Martinez et al. 2008; Nosalewicz and Lipiec 2014).

In assessing the accuracy of the model outputs in comparison to observed data, all statistical analyses were conducted in R (R Core Team 2015), using the 'hydroGOF' package (Zambrano-Bigiarini 2014). RMSE was used to quantify differences between simulated and observed yield and instantaneous soil water content, where a value of zero indicates a perfect model fit (Chai and Draxler 2014). NSE was used to assess the accuracy of model predictions to observed surface runoff and continuous soil moisture. A value of one indicates a perfect fit between simulated and observed values, a value of zero indicates the simulated values are as accurate as the observed mean, and a negative value indicates that the simulated value is less predictive of the observed value than the mean of the observed data (Nash and Sutcliffe 1970).

\section{Objective 2: fertilizer management scenarios}

\section{Whole-watershed simulations}

Six whole-watershed scenarios were simulated, comprised of all combinations of two fertilizer treatments and three precipitation treatments (Table 2). In these simulations, 
Table 2 Six watershed scenarios, with unique total water year (WY) 2013 precipitation treatment and total kg-N ha ${ }^{-1}$ application rate

\begin{tabular}{lll}
\hline Scenario name & Fertilizer treatment $\left(\mathrm{kg}-\mathrm{N} \mathrm{ha}^{-1}\right)$ & Precipitation treatment $(\mathrm{mm})$ \\
\hline VR-70 & Variable-rate $(128)$ & $70 \%$ of observed WY 2013 (423) \\
UN-70 & Uniform $(146)$ & $70 \%$ of observed WY 2013 (423) \\
VR-100 & Variable-rate (128) & $100 \%$ of observed WY 2013 (604) \\
UN-100 & Uniform (146) & $100 \%$ of observed WY 2013 (604) \\
VR-130 & Variable-rate (128) & $130 \%$ of observed WY 2013 (785) \\
UN-130 & Uniform (146) & $130 \%$ of observed WY 2013 (785)
\end{tabular}

which ran from October 1st 2010 through September 30th 2013, only the fertilizer application and precipitation during water year 2013 were modified from the simulation used in the previous section. The two fertilizer treatments were variable-rate (VR) and uniform (UN) fertilizer application. The variable-rate application was the same as in Objective 1 (which was the same method used by the grower for the 2012-2013 winter wheat production year). The uniform management differed only in that the fall $\mathrm{N}$ application rate for the high-zone $\left(101 \mathrm{~kg}-\mathrm{N} \mathrm{ha}{ }^{-1}\right)$ was used across the entire field. The three precipitation treatments were observed water year (WY) 2013 precipitation (100\% of observed precipitation from October 1st, 2012 through September 30th, 2013), a 30\% decrease in precipitation (70\% of WY 2013 precipitation), and a 30\% increase in precipitation (130\% of WY 2013 precipitation). A 30\% increase and decrease were used in this initial study to test simulated response to very dry and very wet years. These scenarios were run using the same crop and soil parameters as in Objective 1.

\section{Economic assessment}

Returns to risk is the value remaining for the operator after paying a fair market return on all factors of production, including labor, management, land and return on equity capital. Thus, it represents earnings to the operator for risking these factors of production in the farming enterprise, which is inherently risky due to uncertainties such as weather, markets, and pests. Risk is not included as a cost, per se, as it would be impossible to quantify a priori. In other words, returns to risk is essentially the value available to the operator to deal with the risk associated with farming. Returns to risk, represented as $R$ in Eq. 6, calculated as crop revenue, represented as yield $(Y)$ multiplied by crop price $(P c)$, less production costs, which are separated into all costs except $\mathrm{N}$ fertilizer, or $C$, and fertilizer expense, represented by the price of $\mathrm{N}$ fertilizer, $\mathrm{Pn}$, multiplied by the quantity of $\mathrm{N}$ fertilizer, or $N$. Returns to risk, or profit, can thus be calculated separately for different assumptions regarding yield and $\mathrm{N}$ rates.

$$
R=[Y \times P c]-[C+(P n \times N)]
$$

The economic conditions in 2013 were used in all calculations of $R$ in this study. The 2013 price per $1000 \mathrm{~kg}(P c)$ of soft white winter wheat was $\$ 248$, the cost of production excluding $\mathrm{N}$ fertilizer $(C)$ was estimated at $\$ 880 \mathrm{ha}^{-1}$ (Davis 2014), and the price of $\mathrm{N}(P n)$ was $\$ 1.70 \mathrm{~kg}^{-1}$. In general, yield gain in response to increasing fertilizer application ( $\mathrm{N}$ availability) follows a concave quadratic function (Baker et al. 2004; Fowler 2003). The input portion of Eq. 6 increases at a constant rate with each increment of additional fertilizer, 
assuming a static price of fertilizer $(P n)$. With each incremental increase in fertilizer (inputs), the output portion of Eq. 6 increases at a diminishing rate until the biophysical maximum yield is attained, at which point additional increases in fertilizer usually result in a loss of yield ( $Y$ ) (Baker et al. 2004). Typically, the economic optimum occurs at a lower yield level than the maximum attainable yield, because at some point the cost of adding another unit of $\mathrm{N}$ is more than the value of the resulting yield gain (Baker et al. 2004).

\section{Results}

\section{Objective 1: model assessment}

CS-MB predicted surface runoff timing and magnitude with an NSE of 0.7 (Fig. 2), considered a "very good" fit (Foglia et al. 2009). The model predicted average profile water content (from the surface to $1.5 \mathrm{~m}$ depth) at the 12 intensive sampling locations during fall and spring of WY 2012 (RMSE $=0.05 \mathrm{~m}^{3} \mathrm{~m}^{-3}, R^{2}=0.66$, range of observed $=0.19-0.50 \mathrm{~m}^{3} \mathrm{~m}^{-3}$ ) and during fall, spring and summer of WY 2013 $\left(\mathrm{RMSE}=0.04 \mathrm{~m}^{3} \mathrm{~m}^{-3}, R^{2}=0.65\right.$, range of observed $=0.22-0.43 \mathrm{~m}^{3} \mathrm{~m}^{-3}$ ) with acceptable accuracy (Fig. 3). The model also accurately simulated continuous soil water content at 15 of 20 micro-site locations (site- and depth-specific) with NSE $\geq 0.4$ (Fig. 4). At all 12 intensive sampling locations, simulated versus observed winter wheat yield fit with an RMSE of $1100 \mathrm{~kg} \mathrm{ha}^{-1}$ (range of observed $=3458-6271 \mathrm{~kg} \mathrm{ha}^{-1}$, Fig. 5). At 10 of the 12 intensive sampling sites, CS-MB predicted crop yield within $840 \mathrm{~kg} \mathrm{ha}^{-1}$ of observed values. The model over-predicted yield at Sites 4 and 11 by 2800 and 2 $150 \mathrm{~kg} \mathrm{ha}^{-1}$, respectively. Within each management zone (low, medium and high fertilizer), the simulated range of yield was similar to yield monitor measurements and the average simulated zone yield was lower than average yield monitor measurement.

\section{Objective 2: fertilizer management and precipitation scenarios}

Uniform fertilizer management resulted in a field average simulated yield increase of 0,3 and $35 \mathrm{~kg} \mathrm{ha}^{-1}$ over variable-rate management in low, medium and high precipitation scenarios, respectively (Fig. 6). Variable-rate fertilizer management resulted in a field

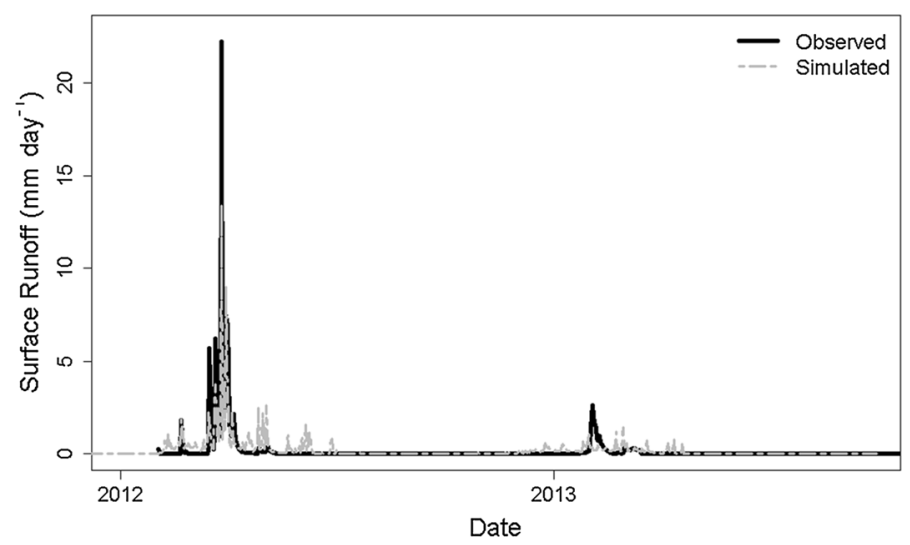

Fig. 2 Simulated (137 mm total) and observed (113 mm total) surface runoff at site; Nash-Sutcliffe $=0.7$ 


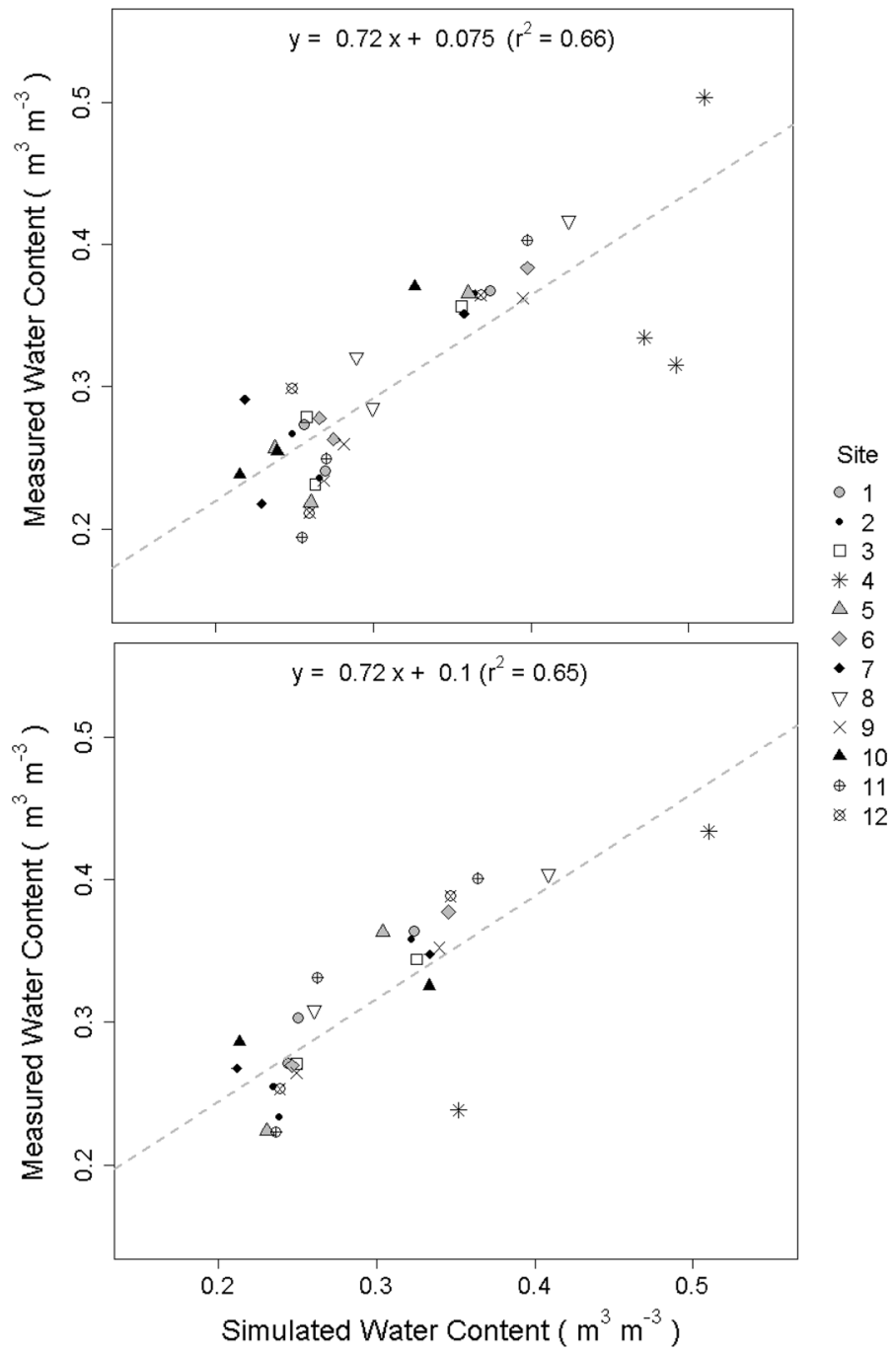

Fig. 3 Simulated and observed average profile (to $1.5 \mathrm{~m}$ depth) volumetric water content in WY 2012 (top panel) and WY 2013 (bottom panel); dotted lines are regression lines

average increase in returns to risk of $\$ 32, \$ 31$ and $\$ 23 \mathrm{ha}^{-1}$ over uniform management in low, medium and high precipitation scenarios, respectively (Fig. 6). The higher returns to risk under variable-rate management follow the spatial distribution of the fertilizer zones, where returns were nearly identical between management types in the high zone $\left(\$ 0-12 \mathrm{ha}^{-1}\right)$, moderately different in the medium zone $\left(\$ 10-60 \mathrm{ha}^{-1}\right)$ and as high as $\$ 87 \mathrm{ha}^{-1}$ greater in the low fertilizer zones (Fig. 6). The model also provides simulated nitrate leaching, runoff losses, crop $\mathrm{N}$ uptake and end-of-season soil $\mathrm{N}$ (Table 3), which were not validated against observational data in this study but are provided as an example of CS-MB model outputs for potential use in future research. Within each fertilizer management type, higher precipitation resulted in higher average yields (Fig. 7) and higher returns to risk. 


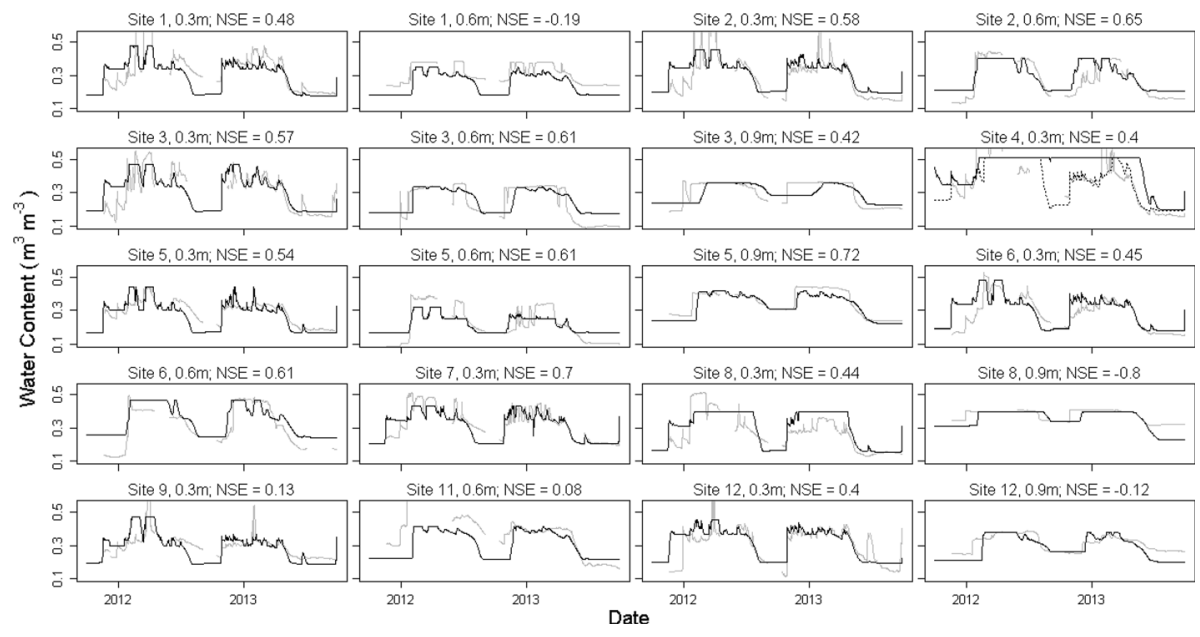

Fig. 4 Simulated (black line) and observed (grey line) continuous volumetric water content; Site 4, $0.3 \mathrm{~m}$ depth dotted black line is simulated water content in adjacent cell (see discussion section)

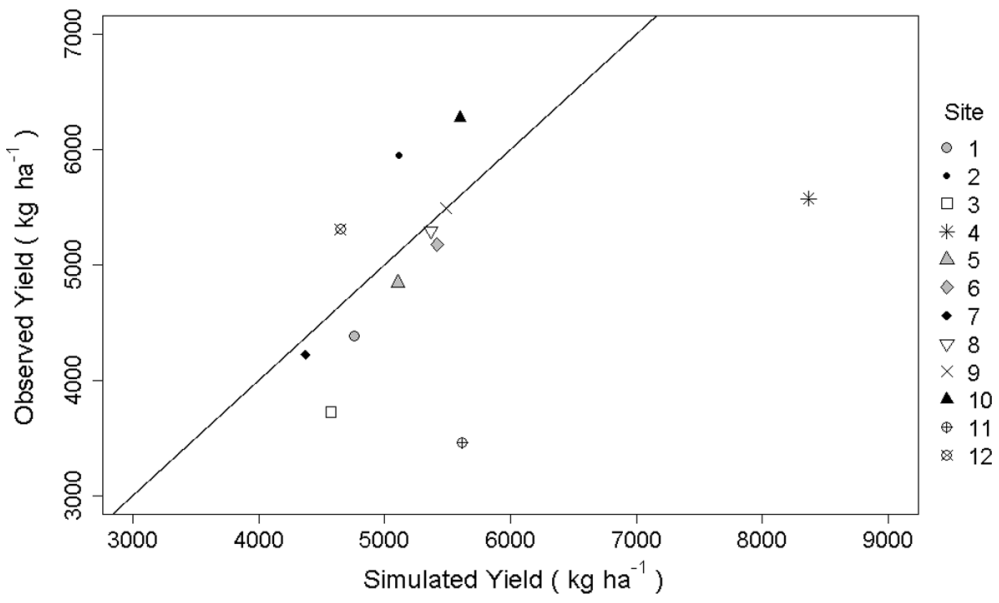

Fig. 5 Simulated and observed soft white winter wheat yield in 2013; the range in simulated yield at these 12 points capture $77 \%$ of the total range in simulated yield across the watershed, solid black line is 1:1 line

\section{Discussion}

This study met the objectives to: (1) assess the ability of CS-MB to predict field-scale variability in water transport and crop yield, and (2) quantify differences in simulated winter wheat harvest metrics and returns to risk between a uniform fertilizer simulation and a variable-rate fertilizer simulation under low, average and high annual precipitation treatments. CS-MB simulated water transport at the study site from 2011 through 2013 and winter wheat production in 2013 with acceptable accuracy (Objective 1). To the authors' knowledge, this is the first application of a field-scale, fully distributed, hydrologic cropping systems model. The fertilizer and precipitation scenarios show that the small gains in yield under uniform management are outweighed by the higher cost of fertilizer, 


\section{Difference in yield}

$($ VR - UN $)=$ kg ha-1 $^{-1}$

$450(\mathrm{VR}>\mathrm{UN})$

$0 \quad(\mathrm{VR}=\mathrm{UN})$

$-450(\mathrm{VR}<\mathrm{UN})$
Difference in returns to risk (VR - UN $)=\$$ ha $^{-1}$

$$
\begin{gathered}
90(V R>U N) \\
0 \quad(V R=U N) \\
-90(V R<U N)
\end{gathered}
$$

High Precipitation: 130\% of WY 2013
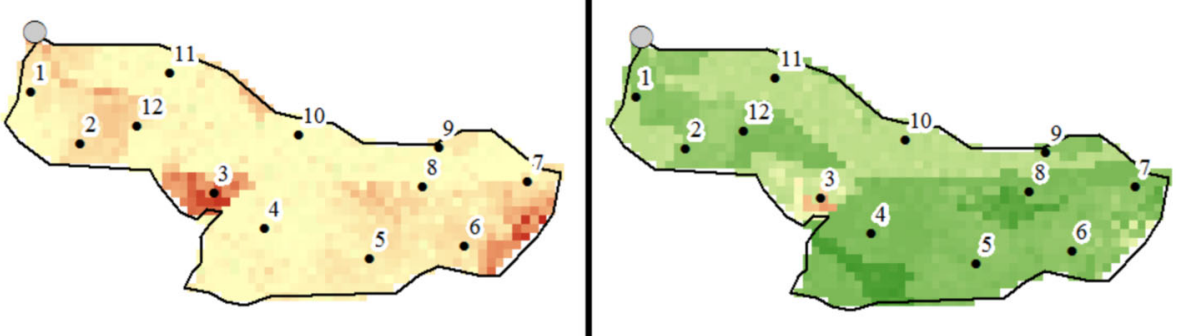

Medium Precipitation: 100\% of WY 2013
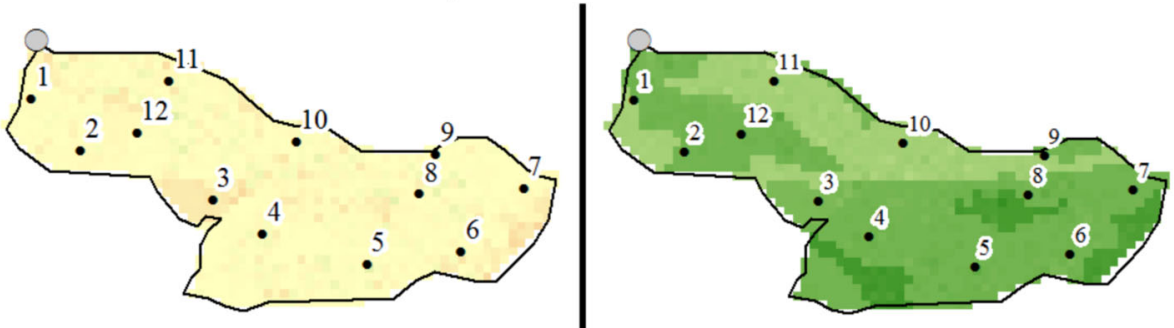

Low Precipitation: 70\% of WY 2013
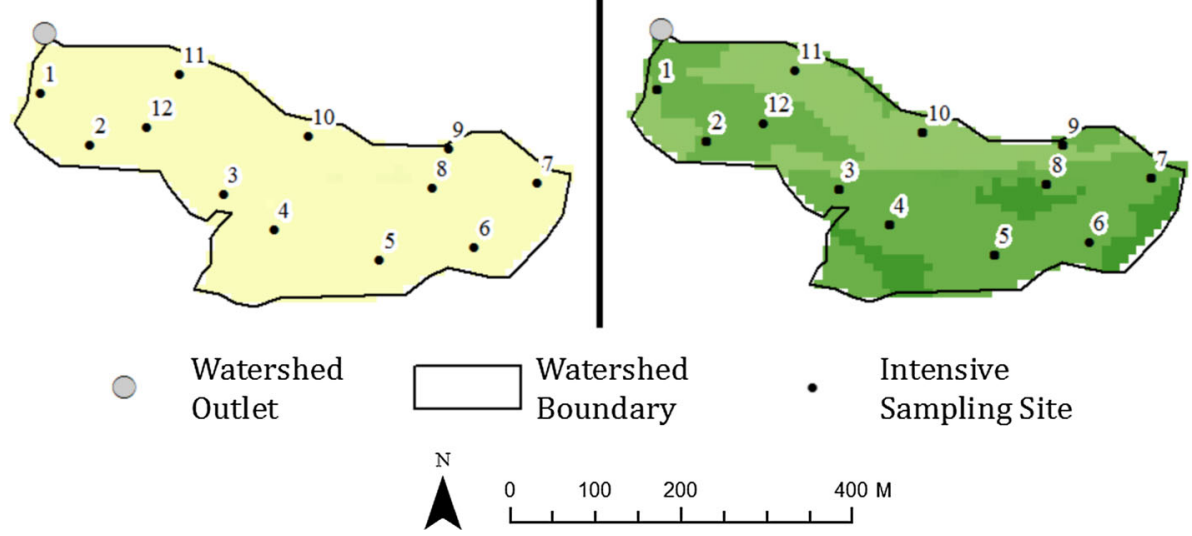

Fig. 6 Change in simulated yield and returns to risk as a result of fertilizer management within each precipitation treatment; areas in red on the left panel maps indicate where uniform management resulted in higher yield; areas in dark green on the right panel maps indicate where returns to risk increased the most under variable-rate management (Color figure online) 


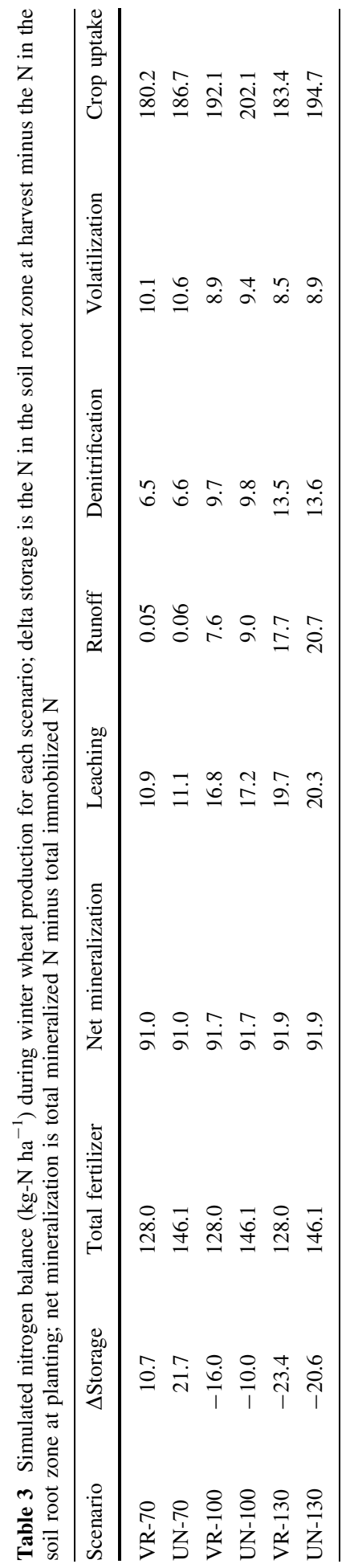



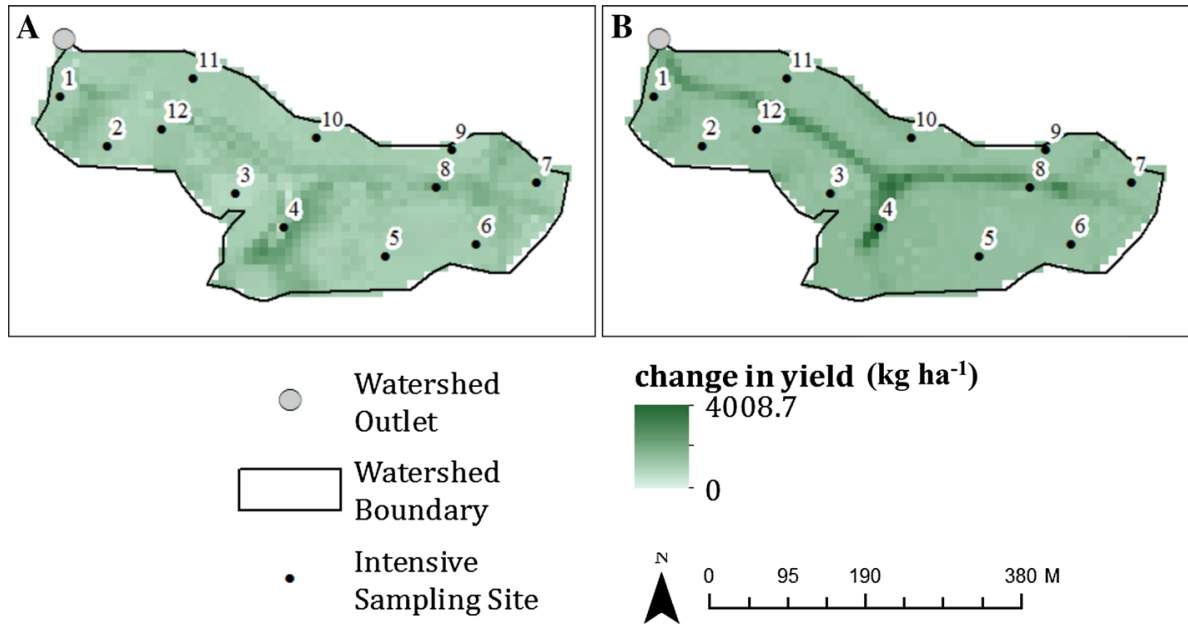

Fig. 7 Change in simulated yield as a result of precipitation treatment under variable-rate management; a shows the yield increase from 100 to $130 \%$ precipitation treatment; b shows the yield increase from 70 to $100 \%$ precipitation treatment; darker areas indicate the greatest yield increase with higher precipitation

resulting in greater returns to risk under variable-rate fertilizer management in all precipitation treatments (Objective 2). This research demonstrates that variable-rate fertilizer application at the field site increases returns to risk in comparison to uniform fertilizer application and that the CS-MB model is a promising tool for future research with its ability to simulate small $\left(10^{\prime} \mathrm{s}\right.$ of hectares) heterogeneous agricultural watersheds with acceptable accuracy.

A close examination of the simulation results at Site 4 indicate limitations in high spatial resolution ( $10^{\prime} \mathrm{s}$ of meters) analysis of simulated results. CS-MB assumes the hydraulic gradient for sub-surface lateral flow calculations is equivalent to the land slope in that direction (i.e. kinematic assumption) rather than using the slope of the water table as the hydraulic gradient. This kinematic assumption is valid for steep topography but it is a known limitation of simulating sub-surface lateral flow on shallow slopes (Wigmosta and Lettenmaier 1999). The difference in simulated water content at Site 4 and the adjacent cell, indicated by the solid black line and dotted black line, respectively, in Fig. 4, highlights the implications for the kinematic assumption on the field site. In August 2012, the simulated depth to water table at Site 4 was $0.3 \mathrm{~m}$ and the depth to water table at the adjacent cell $10 \mathrm{~m}$ away was $0.9 \mathrm{~m}$. The Site 4 cell is $0.15 \mathrm{~m}$ lower in elevation than the adjacent cell, whereas the water table in the Site 4 cell is $0.6 \mathrm{~m}$ higher than in the adjacent cell. Thus, the hydraulic gradient using the kinematic assumption drives water to the Site 4 cell, whereas the slope of the water table indicates flow is actually away from the Site 4 cell. This documented issue in predicting yield in low-lying areas is problematic for assessing small yield gains and associated returns to risk in these areas of the field. However, the accuracy of predictions at the other locations in the field demonstrate that the kinematic approach is acceptable for the goals of this paper and for upslope predictions. In the future, different sub-surface lateral flow algorithms may be needed to delve into temporal variability at small spatial scales (10's of meters) on fields with shallow slopes.

CS-MB enables an examination of field-scale responses to management. In the high precipitation treatment, yield in specific areas of the field were up to $450 \mathrm{~kg} \mathrm{ha}^{-1}$ higher 
with uniform application than with variable-rate $\mathrm{N}$ application (upper left map, Fig. 6). However, these gains in yield were only large enough to offset the additional costs of fertilizer near Site 3 (red shaded area in upper right map, Fig. 6). Returns to risk under variable-rate management averaged $\$ 23-\$ 32 \mathrm{ha}^{-1}$ higher than under uniform management, or a $2-3 \%$ increase in returns to risk with variable-rate management. Given that an average farm in the area is roughly 1000 ha extrapolating these results for the use of variable-rate only just on winter wheat areas (1/3 of the farm in a given year) would result in an additional \$7 666-\$10 666 in returns to risk annually for this size of farm. There is a large range in start-up costs for variable-rate, however; to provide local context, this annual increase in returns to risk would offset the start-up costs for three local co-operator growers within 1-3 year (Ward 2015). Future studies should include additional years of yield data in years with varying precipitation to increase confidence in the simulated response to precipitation and fertilizer treatment.

The spatially-explicit response of winter wheat yield in the high precipitation scenario enables improved understanding of the temporal in-season interaction of $\mathrm{N}$ and water stress along with potential management approaches. The localized increases in yield under uniform management have the greatest per-area-unit response in the high precipitation treatment since the additional water availability enables the plant to make use of the additional $\mathrm{N}$. However, applying excess $\mathrm{N}$ in areas that are water depleted by mid- to lateseason can result in "haying-off" where vigorous early vegetative growth leads to premature soil water depletion, resulting in yield decreases (van Herwaarden et al. 1998a, 1998b). Mid-season N application can improve management of haying-off (Passioura 2002), but the high seasonality of precipitation in the Palouse necessitates earlyseason $\mathrm{N}$ decision making (Pan et al. 2006). Thus, in areas of Palouse fields with very shallow restrictive horizons and severe water limitations that limit crop yield, growers can cut back on the amount of fertilizer and see increases in yield in low to average precipitation years. The effect of temporal interactions of $\mathrm{N}$ and water on wheat yield have been well documented, but understanding is limited to general patterns rather than process knowledge (Barley and Naidu 1964; Brown 2015; Passioura 2006; Storrier 1965; van Herwaarden et al. 1998a). CS-MB currently simulates the relative influence of $\mathrm{N}$ and water stress on yield as a factor with a range of $0-1$, where zero is no stress sensitivity and one is very high stress sensitivity, including a water- $\mathrm{N}$ interactive approach that mimics hayingoff. However, a better understanding of crop physiological processes associated with haying-off might enable CS-MB to more accurately simulate optimum $\mathrm{N}$ management in water limited agricultural fields, furthering the model's ability to contribute to farm management decision-making.

CS-MB is a promising tool because it simulates spatial patterns in crop growth condition in one growing season and enables an examination of crop response to variable annual rainfall. For this initial study, the precipitation treatments are used as a proxy for temporal variability in lieu of long term scenarios due to two factors: (1) computing time limitations in the current version of the model, and (2) since the field is managed in a threeyear rotation, the authors only had one season of observed winter wheat production. Precipitation treatment had a greater effect on simulated yield than fertilizer management (up to $4000 \mathrm{~kg} \mathrm{ha}^{-1}$ increase in yield from low precipitation to average precipitation in comparison to up to $450 \mathrm{~kg} \mathrm{ha}^{-1}$ increase in simulated yield from variable-rate to uniform $\mathrm{N}$ application). The spatial distribution of simulated yield response to precipitation treatment (Fig. 7) follows topography, with the greatest change in simulated yield occurring in the low-lying areas. This is due to sub-surface lateral flow generating a greater effective precipitation in the low-lying areas of the field. In other words, the increase in water 
availability in low lying areas is greater than the increase in precipitation between the low and average precipitation treatments. In future studies, it will be essential to compare the model to observations during variable seasons in order to gain confidence in this simulated response to precipitation.

\section{Conclusion}

This research demonstrated that CS-MB is a promising research tool, capable of simulating a small, variable agricultural watershed with acceptable accuracy in water storage, transport and crop yield. The tool provided an opportunity to assess returns to risk of variable rate strategies which addresses a critical need as there are an increasing number of growers in the Inland Pacific Northwest considering the adoption of variable rate fertilizer strategies. In field site simulations, variable-rate $\mathrm{N}$ application resulted in higher field-average returns to risk than uniform high $\mathrm{N}$ application. This application of a novel, field-scale, hydrologic cropping systems model provides a first look at informing field-scale fertilizer management and improving process understanding of spatial variability, field-scale processes and controls on agro-ecosystems, and farm management practices. Moving forward, CS-MB may be a useful tool to study the effect of climate change on nutrient cycling and transport and associated long-term farm management strategies.

Acknowledgments This research was funded through the Site Specific Climate Friendly Farming (SCF) research grant (United States Department of Agriculture-National Institute of Food and Agriculture award number 2011-67003-30341), with additional research support and open access publishing through the Regional Approaches to Climate Change (REACCH) research grant (United States Department of Agriculture-National Institute of Food and Agriculture award number 2011-68002-30191). This paper was enhanced by field and technical assistance from Todd Anderson, Ryan Boylan, Dave Brown, Emily Bruner, Maninder Chahal, Jan Eitel, Caleb Grant, Ian Harkins, Dave Huggins, Jaimi Lambert, Troy Magney, Matteo Poggio and Lee Vierling.

Funding This research was funded through the Site-Specific Climate Friendly Farming (SCF) research grant (United States Department of Agriculture-National Institute of Food and Agriculture award number 2011-67003-30341), with additional support through the Regional Approaches to Climate Change (REACCH) research grant (United States Department of Agriculture-National Institute of Food and Agriculture award number 2011-68002-30191).

\section{Compliance with Ethical Standards}

Conflict of interest The authors declare that they have no additional real or perceived conflicts of interest.

Open Access This article is distributed under the terms of the Creative Commons Attribution 4.0 International License (http://creativecommons.org/licenses/by/4.0/), which permits unrestricted use, distribution, and reproduction in any medium, provided you give appropriate credit to the original author(s) and the source, provide a link to the Creative Commons license, and indicate if changes were made.

\section{References}

Baker, D. E., Young, D. L., Huggins, D. R., \& Pan, W. L. (2004). Economically optimal nitrogen fertilization for yield and protein in hard red spring wheat. Agronomy Journal, 96(1), 116-123.

Barley, K., \& Naidu, N. (1964). The performance of three Australian wheat varieties at high levels of nitrogen supply. Australian Journal of Experimental Agriculture, 4, 39-48. 
Basso, B., Amato, M., Bitella, G., Rossi, R., Kravchenko, A., Sartori, L., et al. (2010). Two-dimensional spatial and temporal variation of soil physical properties in tillage systems using electrical resistivity tomography. Agronomy Journal, 102(2), 440-449.

Basso, B., Bertocco, M., Sartori, L., \& Martin, E. C. (2007). Analyzing the effects of climate variability on spatial pattern of yield in a maize-wheat-soybean rotation. European Journal of Agronomy, 26, 82-91. doi:10.1016/j.eja.2006.08.008.

Basso, B., Cammarano, D., Chen, D., Cafiero, G., Amato, M., Bitella, G., et al. (2009). Landscape position and precipitation effects on spatial variability of wheat yield and grain protein in southern Italy. Journal of Agronomy and Crop Science, 195, 301-312. doi:10.1111/j.1439-037X.2008.00351.x.

Basso, B., Cammarano, D., Fiorentino, C., \& Ritchie, J. T. (2013). Wheat yield response to spatially variable nitrogen fertilizer in Mediterranean environment. European Journal of Agronomy, 51, 65-70.

Batchelor, W. D., Basso, B., \& Paz, J. O. (2002). Examples of strategies to analyze spatial and temporal yield variability using crop models. European Journal of Agronomy, 18, 141-158.

Beaudette, D. E., Roudier, P., \& O'Green, A. T. (2013). Algorithms for quantitative pedology: a toolkit for soil scientists. Computers \& Geosciences, 52, 258-268.

Bivand, R., Keitt, T., \& Rowlingson, B. (2015). Rgdal: bindings for the geospatial data abstraction library. R package. Retrieved from http://cran.r-project.org/package=rgdal. Accessed on 26 April 2016

Blake, G. R., \& Hartge, K. H. (1986). Bulk density. In A. Klute (Ed.), Methods of soil analysis: Part 1physical and mineralogical methods (2nd ed.). Madison, WI, USA: American Society of Agronomy, Soil Science Society of America.

Booker, J. D., Lascano, R. J., Molling, C. C., Zartman, R. E., \& Acosta-Martínez, V. (2015). Temporal and spatial simulation of production-scale irrigated cotton systems. Precision Agriculture, 16, 630-653. doi:10.1007/s11119-015-9397-6.

Brooks, E. S., Boll, J., \& McDaniel, P. A. (2004). A hillslope-scale experiment to measure lateral saturated hydraulic conductivity. Water Resources Research, 40, W04208. doi:10.1029/2003WR002858.

Brooks, E. S., Boll, J., \& McDaniel, P. A. (2007). Distributed and integrated response of a geographic information system-based hydrologic model in the eastern Palouse region, Idaho. Hydrological Processes, 21, 110-122.

Brooks, E. S., Boll, J., \& McDaniel, P. A. (2012). Hydropedology in seasonally dry landscapes: The Palouse region of the Pacific Northwest. In H. Lin (Ed.), Hydropedology: Synergistic integration of soil science and hydrology (First., pp. 329-350). Oxford, UK: Elsevier.

Brooks, R. H., \& Corey, A. T. (1964). Hydraulic properties of porous media. Hydrology Papers, 3, 1-27.

Brown, T. (2015). Variable rate nitrogen and seeding to improve nitrogen use efficiency. Washington State University, Washington, USA, Doctoral Dissertation.

Chai, T., \& Draxler, R. R. (2014). Root mean square error (RMSE) or mean absolute error (MAE)? Arguments against avoiding RMSE in the literature. Geoscientific Model Development, 7, 1247-1250. doi:10.5194/gmd-7-1247-2014.

Daly, C., Halbleib, M., Smith, J. I., Gibson, W. P., Doggett, M. K., Taylor, G. H., et al. (2008). Physiographically sensitive mapping of climatological temperature and precipitation across the conterminous United States. International Journal of Climatology, 28, 2031-2064. doi:10.1002/joc.

Davis, H. (2014). An economic analysis of a longitudinal survey of wheat growers in the Inland Pacific Northwest. Masters Thesis, University of Idaho, Idaho, USA.

Foglia, L., Hill, M. C., Mehl, S. W., \& Burlando, P. (2009). Sensitivity analysis, calibration, and testing of a distributed hydrological model using error-based weighting and one objective function. Water Resources Research, 45(W06427), 1-18. doi:10.1029/2008WR007255.

Fowler, D. B. (2003). Crop nitrogen demand and grain protein concentration of spring and winter wheat. Agronomy Journal, 95(2), 260-265.

Frankenberger, J. R., Brooks, E. S., Walter, M. T., Walter, M. F., \& Steenhuis, T. S. (1999). A GIS-based variable source area hydrology model. Hydrological Processes, 13(6), 805-822.

Gardner, W. H. (1986). Water content. In A. Klute (Ed.), Methods of soil analysis: Part 1-physical and mineralogical methods (2nd ed.). Madison, WI, USA: American Society of Agronomy, Soil Science Society of America.

Gee, G. W., \& Bauder, J. W. (1986). Particle-size analysis. In A. Klute (Ed.), Methods of soil analysis: Part 1 - physical and mineralogical methods (2nd ed.). Madison, WI, USA: American Society of Agronomy, Soil Science Society of America.

Hengl, T. (2015). GSIF: Global soil information facilities. R package. Retrieved from http://cran.r-project. org/package=GSIF. Accessed on 26 April 2016

Hengl, T., de Jesus, J. M., MacMillan, R. A., Batjes, N. H., Heuvelink, G. B. M., Ribeiro, E., et al. (2014). SoilGrids1 km—global soil information based on automated mapping. PLoS ONE, 9(8), e105992. doi:10.1371/journal.pone.0105992 
Hijmans, R. J. (2015). Raster: geographic data analysis and modeling. R package. Retrieved from http:// cran.r-project.org/package=raster. Accessed on 26 April 2016

Holtan, H. N., England, C. B., Lawless, G. P., \& Schumaker, G. A. (1968). Moisture-tension data for selected soils on experimental watersheds. Washington, USA: Agricultural Research Service, United States Department of Agriculture.

Kemanian, A. R., \& Stöckle, C. O. (2010). C-Farm: a simple model to evaluate the carbon balance of soil profiles. European Journal of Agronomy, 32, 22-29. doi:10.1016/j.eja.2009.08.003.

Malone, R. W., Yagow, G., Baffaut, C., Gitau, M. W., Qi, Z., Amatya, D. M., et al. (2015). Parameterization guidelines and considerations for hydrologic models. Transactions of the ASABE, 58(6), 1681-1703. doi:10.13031/trans.58.10709.

Martinez, E., Fuentes, J.-P., Silva, P., Valle, S., \& Acevedo, E. (2008). Soil physical properties and wheat root growth as affected by no-tillage and conventional tillage systems in a Mediterranean environment of Chile. Soil and Tillage Research, 99, 232-244.

Monteith, J. L. (1965). Evaporation and environment. In G. E. Fogg (Ed), The state and movement of water in living organisms (vol. 19, pp. 205-234). New York, USA: Society for Experimental Biology.

Nash, J., \& Sutcliffe, J. (1970). River flow forecasting through conceptual models Part I-A discussion of principles. Journal of Hydrology, 10(3), 282-290.

Nosalewicz, A., \& Lipiec, J. (2014). The effect of compacted soil layers on vertical root distribution and water uptake by wheat. Plant and Soil, 375, 229-240.

Palosuo, T., Kersebaum, K. C., Angulo, C., Hlavinka, P., Moriondo, M., Olesen, J. E., et al. (2011). Simulation of winter wheat yield and its variability in different climates of Europe: A comparison of eight crop growth models. European Journal of Agronomy, 35, 103-114.

Pan, W., Schillinger, W., Huggins, D., Koenig, R., \& Burns, J. (2006). Fifty years of predicting wheat nitrogen requirements in the Pacific Northwest U.S.A. In Managing crop nitrogen for weather: Integrating weather variability into nitrogen recommendations (pp. 10.1-10.6). Madison, WI, USA: Soil Science Society of America.

Passioura, J. B. (2002). Environmental biology and crop improvement. Functional Plant Biology, 29, 537-546.

Passioura, J. (2006). Increasing crop productivity when water is scarce-from breeding to field management. Agricultural Water Management, 80, 176-196.

Pebesma, E. (2004). Multivariate geostatistics in S: the Gstat package. Computers \& Geosciences, 30, 683-691.

Plant, R. E., Pettygrove, G. S., \& Reinert, W. R. (2000). Precision agriculture can increase profits and limit environmental impacts. California Agriculture, 54(4), 66-71.

R Core Team. (2015). R: a language and environment for statistical computing. Retrieved from http://www. r-project.org/. Accessed on 26 April 2016

Reuter, R. J., McDaniel, P. A., Hammel, J. E., \& Falen, A. L. (1998). Solute transport in seasonal perched water tables in loess-derived soilscapes. Soil Science Society of America Journal, 63, 977-983.

Schillinger, W. F., Papendick, R. I., Guy, S. O., Rasmussen, P. E., \& Van Kessel, C. (2006). Dryland cropping in the Western United States. In G.A. Peterson et al. (ed.) Dryland agriculture. 2nd ed. Agronomy monograph 23. Madison, WI, USA: American Society of Agronomy, Crop Science Society of America and Soil Science Society of America.

Searcy, J. K., \& Hardison, C. H. (1960). Double-mass curves. US Geological Survey Water-Supply Paper 1541-B. USGS, Washington, DC, USA

Singh, A. K., Tripathy, R., \& Chopra, U. K. (2008). Evaluation of CERES-Wheat and CropSyst models for water-nitrogen interactions in wheat crop. Agricultural Water Management, 95(7), 776-786.

Stöckle, C. O., \& Campbell, G. S. (1989). Simulation of crop response to water and nitrogen: an example using spring wheat. Transactions of the ASAE, 32(1), 66-74.

Stöckle, C. O., Donatelli, M., \& Nelson, R. (2003). CropSyst, a cropping systems simulation model. European Journal of Agronomy, 18, 289-307.

Stöckle, C. O., Kemanian, A. R., Nelson, R. L., Adam, J. C., Sommer, R., \& Carlson, B. (2014). CropSyst model evolution: From field to regional to global scales and from research to decision support systems. Environmental Modelling \& Software, 62, 361-369.

Storrier, R. (1965). Excess soil nitrogen and the yield and uptake of nitrogen by wheat in southern New South Wales. Australian Journal of Experimental Agriculture, 5, 317-322.

Stöckle, C. O., Higgins, S., Kemanian, A., Nelson, R., Huggins, D., Marcos, J., et al. (2012). Carbon storage and nitrous oxide emissions of cropping systems in eastern Washington: A simulation study. Journal of Soil and Water Conservation, 67(5), 365-377. doi:10.2489/jswc.67.5.365. 
Sudduth, K. A., Drummond, S., \& Kitchen, N. R. (2001). Accuracy issues in electromagnetic induction sensing of soil electrical conductivity for precision agriculture. Computers and Electronics in Agriculture, 31, 239-264.

van Herwaarden, A. F., Angus, J. F., Richards, R. A., \& Farquhar, G. D. (1998a). "Haying-off", the negative grain yield response of dryland wheat to nitrogen fertiliser II. Carbohydrate and protein dynamics. Australian Journal of Agricultural Research, 49, 1083-1093.

van Herwaarden, A. F., Farquhar, G. D., Angus, J. F., Richards, R. A., \& Howe, G. N. (1998b). "Hayingoff", the negative grain yield response of dryland wheat to nitrogen fertiliser I. Biomass, grain yield, and water use. Australian Journal of Agricultural Research, 49, 1067-1081.

Ward, N. K. (2015). Improving agricultural nitrogen use through Policy Incentivized Management Strategies: Precision agriculture on the Palouse. MS Thesis: University of Idaho, ID, USA. Retrieved from http://digital.lib.uidaho.edu/cdm/ref/collection/etd/id/862. Accessed on 3 March 2017

Wickham, H. (2011). The split-apply-combine strategy for data analysis. Journal of Statistical Software, $40(1), 1-29$.

Wigmosta, M. S., \& Lettenmaier, P. (1999). A comparison of simplified methods for routing topographically driven sub-surface flow. Water Resources, 35(1), 255-264.

Yang, C., Peterson, C. L., Shropshire, G. J., \& Otawa, T. (1998). Spatial variability of field topography and wheat yield in the Palouse Region of the Pacific Northwest. Transactions of the ASAE, 41(1), 17-27.

Zambrano-Bigiarini, M. (2014). hydroGOF: goodness-of-fit functions for comparison of simulated and observed hydrological time series. Retrieved from http://cran.r-project.org/package=hydroGOF. Accessed on 26 April 2016

Zhang, X., Shi, L., Jia, X., Seielstad, G., \& Helgason, C. (2010). Zone mapping application for precisionfarming: A decision support tool for variable rate application. Precision Agriculture, 11, 103-114. 